\title{
Evaluating Frozen Strawberries as a Strategy for Thirst Management in Patients with Congestive Heart Failure (CHF)
}

\author{
D. Hudiyawati ${ }^{\mathrm{a}}$, D. L. Suswardany ${ }^{\mathrm{b}}$, \\ ${ }^{\text {a }}$ School of Nursing, Faculty of Health Science, Universitas Muhammadiyah Surakarta, Indonesia \\ ${ }^{\mathrm{b}}$ Department Public Health, Faculty of Health Science, Universitas Muhammadiyah Surakarta, Central Java Indonesia
}

\section{ABSTRACT}

INTRODUCTION: Thirst sensation in Congestive Heart Failure (CHF) patients is caused by diuretic administration and fluid consumption limitation. Unhandled thirst sensation leads to a disobedient patient in fluid consumption limitation that causes the patient condition to worsen. This research aimed to analyse the frozen strawberries administration's effects on the thirst sensation in a patient with CHF. MATERIAL AND METHOD: The method used was a quasi-experiment with a pre-test and post-test control group design. The number of respondents was 34 patients divided into two groups: 17 respondents in the intervention group and 17 respondents in the control group. The sampling technique was stratified random sampling based on NYHA classification in the respondents. Frozen strawberries were given to the intervention group, while ice cubes were given to the control group. All the data were analyzed using a t-test. RESULT: The results showed that the mean score of the thirst intensity of the intervention and control group was 4.44 and 2.35 , respectively. The independent t-test of the mean difference of thirst intensity pre and post-test between the intervention and control groups was $\mathrm{p}=0.001$. According to the paired t-test analysis, the thirst intensity score between pre-test and post-test was $\mathrm{p}<0.001$, from moderate to low thirst intensity. CONCLUSION: Frozen strawberries were statistically effective in reducing the thirst intensity in a patient with CHF.

KEYWORDS: CHF, fluid restrictions, frozen strawberry, interventions, thirst.

\section{INTRODUCTION}

Heart failure is a clinical syndrome that is often associated with a decrease in activity tolerance and fluid retention due to impaired heart function. Signs and symptoms of fluid retention are usually seen first in the patient's haemodynamic status compared with the clinical symptoms that appear, such as respiratory distress, pulmonary oedema, crackles, and swelling in the legs. Although clinical symptoms are no longer visible,

\section{Corresponding Author:}

Dr. D. Hudiyawati

School of Nursing, Faculty of Health Science,

Universitas Muhammadiyah Surakarta,

Jl. Jendral Ahmad Yani, Pabelan, Kartasura-Surakarta 57102, Indonesia.

Tel No: (+62) 85697521219

Email : dian.hudiyawati@ums.ac.id the patient's haemodynamics still show congestion, leading to a poor prognosis. ${ }^{1-4}$

An increasing number of CHF sufferers in Indonesia has made the health professional team collaborate to improve CHF patients' care. ${ }^{2}$ The management of CHF attempted by a team of health professionals in Indonesia includes treating the causes of $\mathrm{CHF}$, cardiac resynchronization therapy, fluid restriction therapy, diuretics, vasodilators, or ACE inhibitors, digoxin, and home independent care management. ${ }^{5}$ Management has not shown optimal results as evidenced by CHF patients who are still undergoing repeated hospitalization. ${ }^{6}$ Data showed that by 30 days, the readmission rate of heart failure patients in hospitals in Asia was 3-15\%.7 
Patients who do not adhere to the therapy program have a 6.86 times greater risk of being hospitalised more than once a year compared to those who comply. ${ }^{7}$ One of the causes of hospitalisation is hypervolaemia, caused by patients' non-compliance with fluid restriction therapy. ${ }^{8}$ It is triggered by the thirst felt by patients. ${ }^{1,9,10}$ Undetectable hypervolaemia increases the workload of the heart, thus falling into a condition of pumping failure which ultimately results in death or urgent cardiac transplantation. ${ }^{8}$

Thirst is one of the physiological effects that arise in CHF patients. Thirst is a physiological process of the body that responds to the lack of fluid in the body. Waldreus et al obtained data on CHF patients who felt a permanent thirst of $18.6 \% .{ }^{11}$ Other data based on studies by Albert et al, showed that 40 out of $50 \mathrm{CHF}$ patients also experienced thirst. ${ }^{1}$ Similar to a study conducted by Holst stated that thirst scores were higher in patients with fluid restriction $1500 \mathrm{ml} /$ day compared with patients without fluid restriction $(51 \mathrm{~mm} ; 23 \mathrm{~mm}) .{ }^{9}$ Thirst score is higher among patients with fluid restriction therapy than patients without fluid restriction, because patients cannot drink according to desire. ${ }^{1,9,12}$

Interventions to reduce thirst include giving cold drinks, ice cubes, frozen fruit, peppermint, or low-sugar consumption. ${ }^{1,10,13}$ Sacrias stated the intervention of using ice cubes in reducing thirst that sucking ice cubes was significantly decreasing thirst in patients undergoing haemodialysis in a tertiary care teaching hospital, South India. The results of research by Sacrias et al. showed that the thirst (severe thirst) decrease by sucking ice cubes $(35 \%)$ more effectively than the control group $(5 \%) .{ }^{14}$ The use of ice cubes has proven to be more effective in reducing thirst but has not been explained for how long the thirst can be reduced. Another study conducted by Salata et al. explained that the use of ice cubes could reduce thirst, but within 30 minutes then thirst is felt again. ${ }^{15}$ To overcome its problem, the current study wants to combine cold temperature and strawberries.

In a previous study, Weiland argues that there are several ways to alleviate thirst, one of which is by using frozen fruit. The fruits that can be used for this procedure are grapes and strawberries. ${ }^{17}$

IMJM Volume 20 No.2, Apr 2021
The combination of cold temperatures and strawberries that have a sour taste is expected to reduce thirst longer compared to ice cubes. Frozen strawberry is one of the interventions that can be used to reduce thirst. Cold temperatures can stimulate oropharyngeal receptors, which could reduce thirst sensations. ${ }^{15}$ Oropharyngeal receptor stimulation also affects the suppression of the secretion of vasopressin hormones, which play a role in increased thirst. ${ }^{16,17}$ Strawberry is a type of fruit that has a refreshingly sour taste. The acid taste sensation is a stimulant with the greatest influence in stimulating high amounts of salivary secretion, which causes saliva to become more watery. ${ }^{18}$ The type of strawberries used in this study were Fragaria sp cv. Holibert. The average size of it is around $>20$ grams, with a vitamin $\mathrm{C}$ content of 2 $\mathrm{mg} / 100$ grams of fruit, titrated acid content of $5 \mathrm{mg} /$ 100 gram of fruit, $90 \%$ water content, and stored at 4 degrees Celsius with a long storage time of 11 days. ${ }^{21}$ The purpose of this study was to determine the effects of frozen strawberries on the thirst intensity in CHF patients.

\section{MATERIALS AND METHODS}

This study was an experimental study with the method of pre-test and post-test control group design. ${ }^{19}$ The study sample was $34 \mathrm{CHF}$ patients who experienced thirst in Dr. Moewardi Hospital in Surakarta, Indonesia. The sampling method was stratified random sampling based on NYHA II, NYHA III, and NYHA IV classification to select the control and intervention groups. The patients were randomised to the intervention and control group using the lottery method. Inclusion criteria were patients who were willing to receive the frozen strawberry intervention, had stable haemodynamics, CHF NYHA II-IV, CHF patients who experienced thirst, daily fluid allowance between $500-1000 \mathrm{ml}$, and aged 18 years or more.

The study was conducted after obtaining permission from the Medical Research Ethics Committee from Diponegoro University, Indonesia. Respondents were given clear explanations of the study's purpose and filled out informed consent before the study was conducted. Confidentiality is maintained throughout the research.

The research's preliminary data included respondents' characteristics (age, gender, NYHA classification, diuretic 
dose, amount of fluid consumed, and amount of IV fluid) and the intensity of thirst before intervention (pretest value). Respondents in the intervention group were given frozen strawberries (20 grams) five times every two hours a day from 09.00 - 17.00 for two days, while the control group was assigned ice cubes $(5 \mathrm{ml})$ with the same dose. Post-test scores are taken at the end of the intervention session. Intervention is carried out during the day because the heat during the day will give more thirst, and the average length of stay of CHF patients at cardiac ward Moewardi Hospital is 4-5 days.

The use of frozen fruit is more recommended than frozen fruit juice because the juice-making process will damage the fruit's substances. Moreover, it will increase glucose and water levels. Therefore, this study prepares frozen fruit using whole fruit. The first step was to choose fresh red strawberries of good quality. The fruits were then washed and dried. Next, the fruits were cut by adjusting the desired weight of 20 grams. They were then put into a tray and froze to a temperature of 0 degrees Celsius.
Once the fruit has frozen, they were put in a small plastic bag and placed back in the freezer. The researcher is assisted by a nurse on duty to provide frozen fruits according to schedule, and the nurse will also measure the patient's thirst level on the monitoring sheet provided.

Descriptive analysis such as frequency, percentage, average, and standard deviation is used to examine respondents' characteristics. An independent t-test was used to compare the thirst intensity between the intervention group and the control group; a paired t-test was used to determine the effect of giving frozen strawberries on CHF patients' thirst sensation.

\section{RESULTS}

The current results depict the demographic and clinical data of respondents, differences in the intensity of thirst on intervention and control group, and the effect of giving frozen strawberries to CHF patients' thirst.

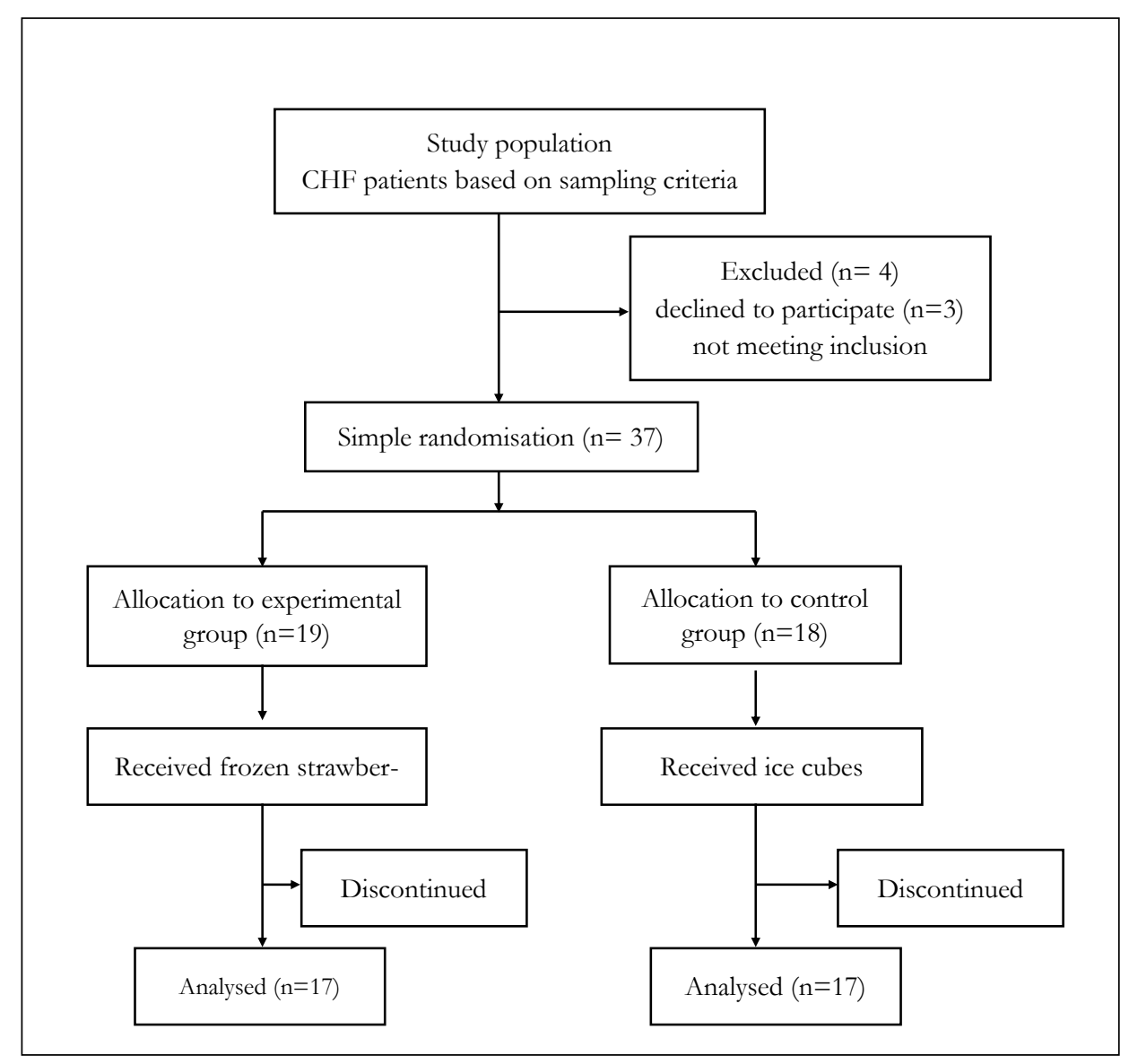

Fig 1. Flow of sampling 
The characteristics of respondents based on age, gender, NYHA classification, amount of fluid consumption, and amount of intravenous fluid there were no significant differences $(p>0.05)$ between the two groups (Table I).

Table I. Distribution of CHF Patient Characteristics

\begin{tabular}{|c|c|c|c|c|c|c|c|c|}
\hline \multirow[t]{2}{*}{ No } & \multirow[t]{2}{*}{ Variable } & \multicolumn{2}{|c|}{$\begin{array}{l}\text { Intervention } \\
\text { Groups }\end{array}$} & \multicolumn{2}{|c|}{$\begin{array}{l}\text { Control } \\
\text { Groups }\end{array}$} & \multicolumn{2}{|c|}{ Total } & \multirow[t]{2}{*}{$\begin{array}{c}\mathrm{p}- \\
\text { value* }\end{array}$} \\
\hline & & $\begin{array}{l}(\mathrm{N}= \\
17)\end{array}$ & $\%$ & $\begin{array}{l}(\mathrm{N}= \\
17)\end{array}$ & $\%$ & $\begin{array}{l}(\mathrm{N}= \\
34)\end{array}$ & $\%$ & \\
\hline \multirow[t]{4}{*}{1} & Age (year) & & & & & & & 0.512 \\
\hline & $20-40$ & 3 & 17.7 & 1 & 5.9 & 4 & 11.75 & \\
\hline & $41-60$ & 11 & 64.9 & 11 & 64.9 & 22 & 64.72 & \\
\hline & $>60$ & 3 & 17.7 & 5 & 29.5 & 8 & 23.53 & \\
\hline \multirow[t]{3}{*}{2} & Gender & & & & & & & 1.000 \\
\hline & Male & 10 & 58.8 & 11 & 64.7 & 21 & 61.77 & \\
\hline & Female & 7 & 41.2 & 6 & 35.3 & 13 & 38.23 & \\
\hline \multirow[t]{5}{*}{3} & NYHA & & & & & & & 0.536 \\
\hline & Classification & 5 & 29.4 & 5 & 29.4 & 10 & 29.42 & \\
\hline & II & 5 & 29.4 & 5 & 29.4 & 10 & 29.42 & \\
\hline & III & 7 & 41.2 & 7 & 41.2 & 14 & 41.16 & \\
\hline & IV & & & & & & & \\
\hline \multirow[t]{6}{*}{4} & Liquid & & & & & & & 0.546 \\
\hline & consumed & & & & & & & \\
\hline & $(\mathrm{ml} / 24$ & 12 & 70.6 & 7 & 41 & 19 & 55.5 & \\
\hline & hours) & 5 & 29.4 & 10 & 59 & 15 & 44.5 & \\
\hline & $500-750$ & & & & & & & \\
\hline & $751-1000$ & & & & & & & \\
\hline \multirow[t]{8}{*}{5} & Diuretic & & & & & & & 0.413 \\
\hline & dose & 5 & 29.4 & 1 & 5.9 & 6 & 17.66 & \\
\hline & $20 \mathrm{mg} / 24$ & 6 & 35.3 & 12 & 70.6 & 18 & 52.94 & \\
\hline & hours & 6 & 35.3 & 4 & 23.5 & 10 & 29.4 & \\
\hline & $20 \mathrm{mg} / 12$ & & & & & & & \\
\hline & hours & & & & & & & \\
\hline & $20 \mathrm{mg} / 8$ & & & & & & & \\
\hline & hours & & & & & & & \\
\hline \multirow[t]{6}{*}{6} & Amount of & & & & & & & 0.076 \\
\hline & IV fluid & & & & & & & \\
\hline & (ml/ hour) & 9 & 53 & 6 & 35.3 & 15 & 44.2 & \\
\hline & 20 & 8 & 47 & 9 & 53 & 17 & 49.92 & \\
\hline & 30 & 0 & 0 & 2 & 11.7 & 2 & 5.88 & \\
\hline & $>30$ & & & & & & & \\
\hline
\end{tabular}

The thirst intensity for all respondents before the intervention was categorised as moderate thirst (score 4-6). The distribution of respondents' thirst intensity in each NYHA classification differs from each level (Fig.2). Between the thirst intensity and NYHA classification scores have an un-directional relationship. The lower the NYHA classification level, the thirst intensity score is also small. In contrast, the higher the NYHA classification level, the thirst intensity score will also increase.

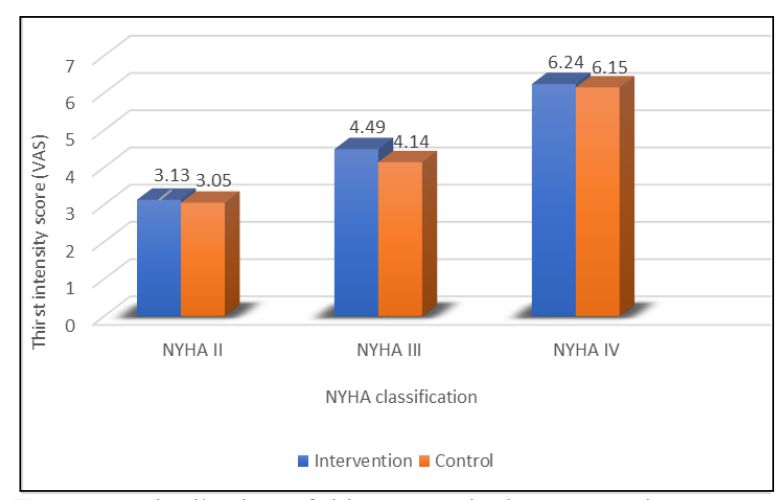

Figure 2 Distribution of thirst Intensity in CHF Patients (before intervention
Based on the level of thirst, both in the intervention and control groups, most patients were at moderate thirst. However, after being given the intervention, thirst intensity in the intervention group was low (65\%) and not thirsty $(35 \%)$. while thirst in the control group changed to low $(76 \%)$ and moderate $(24 \%)$ (Table II).

Table II. The Level of Thirst Intensity in Intervention and Control Group

\begin{tabular}{lcccc}
\hline \multirow{2}{*}{$\begin{array}{c}\text { Thirst } \\
\text { Intensity }\end{array}$} & $\begin{array}{c}\text { Frequency } \\
(\mathbf{n}=\mathbf{1 7})\end{array}$ & $\begin{array}{c}\text { Percentage } \\
(\%)\end{array}$ & $\begin{array}{c}\text { Frequency } \\
(\mathbf{n}=17)\end{array}$ & $\begin{array}{c}\text { Percentage } \\
\mathbf{( \% )}\end{array}$ \\
\hline \multicolumn{2}{l}{ Intervention group } & & & \\
No & - & - & 6 & 35 \\
Low & 4 & 23.5 & 11 & 65 \\
Moderate & 9 & 53 & - & - \\
High & 4 & 23.5 & - & - \\
Control group & & & & \\
Low & 2 & 12 & 13 & 76 \\
Moderate & 13 & 76 & 4 & 24 \\
High & 2 & 12 & - & - \\
\hline
\end{tabular}

The thirst intensity score between pre and post procedures in the intervention and control group was significantly different (Table III). The data analysis obtained a p-value was 0.001 . It significantly decreased the average score of thirst before and after being given frozen strawberries. Although the control group that assigned ice cubes also showed significant results. The delta mean of thirst intensity in the intervention group was higher than the control group.

Table III. Effect of Frozen Strawberries on Intensity of Thirst in CHF Patients

\begin{tabular}{llllll}
\hline Variable & Therapy & Mean & SD & SE & $\begin{array}{l}\text { p- } \\
\text { value* }\end{array}$ \\
\hline Intervention & Pre & 4.56 & \pm 1.384 & 21.27 & 0.001 \\
& Post & 0.12 & \pm 0.919 & & \\
Control & Pre & 4.20 & \pm 1.138 & 20.43 & 0.001 \\
& Post & 1.85 & \pm 0.842 & & \\
\hline
\end{tabular}

The data analysis obtained t-count and p-value of $(\mathrm{t}=5.47 ; \mathrm{p}=0.001)$, there was a difference in thirst between the intervention and control groups. The results showed that frozen strawberry consumption significantly reduced thirst for CHF patients (Table IV).

Table IV. Analysis of Differences in Thirst Intensity between Intervention and Control Groups in CHF Patients

\begin{tabular}{lcclll}
\hline Variable & $\mathbf{N}$ & Mean & SD & T & p-value* \\
\hline Intervention & 17 & 4.44 & \pm 0.666 & 5.47 & 0.001 \\
Control & 17 & 2.35 & \pm 0.474 & & \\
\hline * & & & & \\
\hline
\end{tabular}

*Independent sample t-Test 


\section{DISCUSSION}

The majority of participants in this study were in the adult age range $(64.9 \%)$. This result was in line with the study by Riegel et al. (2019), which stated that the average age of heart failure patients was 59 years old. ${ }^{23}$ Previous literature studies conveyed different results; the mean age of respondents was over 60 years. ${ }^{24}$ The life expectancy of CHF patients in developed countries is higher than in developing countries such as Indonesia. More than $50 \%$ of CHF patients were male $(58.8 \%)$. A study from Polanska et al. (2020) also had similar results; most CHF patients encountered in their study were male. The various CHF patients' condition in the current study was in the NYHA II-IV, consistent with previous studies. ${ }^{23,24}$ The state of CHF patients in NYHA II-IV is more often found in patients who are hospitalised. Since, in this condition, the patient shows symptoms, so health care must be done.

All participants in this study received diuretic therapy with various doses. Diuretic therapy is recommended for heart failure patients, especially those with signs and symptoms of fluid retention. Diuretic therapy has also been shown to improve conditions and activity tolerance. ${ }^{25}$ Study Polanska et al. (2020) also found that $80.8 \%$ of CHF patients received diuretic therapy. ${ }^{24}$ In addition to diuretic therapy, fluid restriction is also applied to CHF patients based on recommendations by considering body weight, namely $30 \mathrm{ml} / \mathrm{kg}$ per day. ${ }^{26}$ Nevertheless, in the current study, participants were advised to restrict fluid to $1500-2000 \mathrm{ml} /$ day.

A picture of thirst for all respondents on the first and second days is categorized as moderate thirst (4-7). The distribution of respondents' thirst intensity on each NYHA classification differs from each level. Therefore, it can be seen that disease conditions also influence the intensity of thirst.

The current study result was in line with Albert's study finding that all CHF patients also experience thirst. The average intensity of thirst for patients around 4-6 categorised as moderate thirst from NYHA II, III, and IV classifications is not much different in the present study. Most of the NYHA classification of respondents in this study was NYHA III. ${ }^{1}$ A study from Aliti et al. stated that $\mathrm{CHF}$ patients experience thirst with an average thirst intensity score of 5.10 medium thirst categories. The score of thirst intensity in the Aliti study is greater than the current research because the NYHA classification of respondents in this study are NYHA III and NYHA IV. ${ }^{11}$

The thirst intensity in the intervention group seems to have decreased. In the group, given ice cubes, the thirst intensity also reduced on the first, second, and two days. The two groups' analysis results experienced a significant decrease, but in the frozen strawberry group, the difference in the decline was more significant than the ice cubes group.

The result is in line with the theory that CHF patients' thirst arises due to several conditions, including the worsening condition of heart failure, loss of body fluids caused by diuretic use, and fluid restriction therapy. ${ }^{10,11,20}$ The study of Waldreus found that thirst intensity of CHF patients tends to persist in patients' deteriorating conditions, which were followed up in the third, sixth, and ninth weeks. ${ }^{11}$

Thirst is a physiological process that responds to a lack of fluid in the body. One condition that affected the thirst in CHF patients is caused by changes in plasma volume. A decrease in plasma volume will increase the level of angiotensin II. Thirst receptors will stimulate the center of thirst for the brain. Sympathetic and neurohormonal adaptation to CHF affects the regulation of the fluid. ${ }^{9}$

The results showed that there were significant differences in the thirst intensity of CHF patients between groups. Based on these results, the percentage decrease in thirst intensity in the group that given frozen strawberries is more significant than the group given ice cubes. The power of thirst of respondents in the group given frozen strawberries decreased by $34 \%$, while in the control group decreased by $23 \%$.

These results differ from the intervention of Sacrias in a study entitled "Effect of Nursing Interventions on Thirst and Interdialytic Weight Gain of Patients with Chronic Kidney Disease Subjected to Hemodialysis". In this study, Sacrias used a maximum dose of 10 times 
the intervention. However, by looking at current research giving five times the amount of frozen strawberry can reduce thirst in CHF patients. ${ }^{14}$

The mechanism of decreased thirst by using frozen strawberry is through the stimulation of oropharyngeal receptors and salivary secretions. The cold sensation of frozen strawberry will stimulate oropharyngeal receptors that suppress AVP secretion so that the AVP level will decrease and thirst will decrease. ${ }^{15,17}$ Oropharyngeal sensors are visceral sensor afferent fibers found in the trigeminal and glossopharyngeal nerves; they are sensitive to cold temperature stimuli. Cell bodies of afferent fibers in the trigeminal nucleus lie in the spinal trigeminal nucleus, whereas afferent fibers from the terminal glossopharyngeal nerve are located in the solatorius nucleus in the medulla. The study about retrograde axonal flow shows that afferent fibers spread from the solarium and terminal nuclei to the supra-optic nucleus and sub-fornical organs, which are known as areas that contribute to the control of thirst and AVP secretion. ${ }^{22}$ Therefore, in the presence of cold stimulation, the oropharyngeal receptor will suppress AVP secretion, and the thirst will be controlled. In addition to the cold sensation, decreasing thirst with frozen strawberry is also through stimulation of salivary secretions due to strawberry's sour taste. Salivary secretion can increase in two ways, namely by stimulation or without stimulation.

Salivary secretion by stimulation occurs when pressure chemoreceptors in the oral cavity respond to food. These receptors start impulses on afferent nerve fibers that carry information to the center of saliva in the medulla of the brain stem, then at the center of saliva sending, impulses through the extrinsic nerve autonomy to the salivary gland aims to increase salivary secretion. The salivary secretion will increase with stimulation reaching around $1.5-2.5 \mathrm{ml} / \mathrm{min}$ and will increase 10 fold, even more, when the salivary glands are stimulated through mastication or the presence of acidic foods such as strawberries. ${ }^{18}$

Unstimulated salivary secretion is the production of saliva which, occurs in the absence of stimulation in the oral cavity. Salivary secretion occurs when a person only thinks, sees, smells, or hears good or sour types of food. 23 Strawberry is one type of fruit that has a refreshingly sour taste. The acidic sensation of strawberry will stimulate high amounts of salivary secretions that cause saliva to become thick, and just thinking about salivary secretions has increased. Therefore, strawberries can increase salivary secretion either through stimulation (chewing or feeling) and without stimulation (think about it). Increasing the amount of saliva in the oral cavity will overcome dry mouth symptoms which, is one of the factors causing thirst. The mouth and throat will become moist due to increased salivary flow so that thirst can be reduced.

A short interview that the researcher did during data collection found that the respondents' continuous thirst made respondents unable to control drinking, thus ignoring the recommended fluid restriction. Respondents stated that giving frozen strawberries made the desire to drink more controlled than before because the mouth feels fresher and the throat does not dry. Respondents also did not state any complaints or side effects from the frozen strawberries.

The effect size of frozen strawberry based on the formula from Cohen's D for two days is 3.6 (very strong). Effect size from previous studies on "Effectiveness of Low Sugar Chewing Gum and Chilling Ice Cubes on Decreasing Thirst in Patients with Chronic Kidney Disease Undergoing Hemodialysis" obtained a value of 2.5 (very strong). The effect size of the two interventions is different, where frozen strawberry has greater strength than ice cubes, due to the combination of cold sensation and sour taste of the strawberry. Both of these will together stimulate oropharyngeal receptors and salivary secretion in reducing thirst. Whereas ice cubes only use a cold sensation to reduce thirst. Based on the explanation above, frozen strawberries can be used to reduce thirst in CHF patients. The thirst that is adequately handled aims so that patients can adhere to fluid restriction therapy so that an imbalance in fluid volume or hypervolaemia in $\mathrm{CHF}$ patients does not occur.

However, these study results were limited by the number of sample sizes and the random allocation of the respondents, which may enhance selection bias. Because of these limitations, future research is 
recommended to include several study locations, larger sample sizes, and research designs that will consider the real randomisation and blinding process.

\section{CONCLUSION}

Thirst is a real physiological impact on CHF patients. The intensity of thirst increases with worsening condition of the disease. Independent nursing intervention in the form of frozen strawberries proved effective in reducing the intensity of thirst for $\mathrm{CHF}$ patients receiving fluid restriction therapy. Thus, giving frozen strawberries can be used as an intervention to reduce thirst in $\mathrm{CHF}$ patients.

\section{CONFLICT OF INTEREST}

The authors declare that there is no conflict of interest.

\section{AKNOWLEDGEMENT}

This study received no grants from funding agencies in the public or non-profit sector.

\section{REFERENCES}

1. Albert NM, Nutter B, Forney J, Slifcak E, Tang WHW. A randomized controlled pilot study of outcomes of strict allowance of fluid therapy in hyponatremic heart failure (SALT-HF). J Card Fail. 2013;19(1):1-9.

2. Nicholson C. Heart Failure : A Clinical Nursing Handbook. Chicester: John Wiley and Sons; 2007.

3. Williams L, Hopper P. Understanding medical surgical nursing. 3rd ed. Philadelphia: Davis company; 2007.

4. Williams L, Wilkins. Medical surgical nursing: Made incredible easy. 3rd ed. JC. Burghardt; 2012.

5. Philipson H, Ekman I, Swedberg K, Schaufelberger M. ORIGINAL ARTICLE A pilot study of salt and water restriction in patients with chronic heart failure. 2010;(October 2009):209-14.

6. Smeltzer, C.S., Bare, B.G., Hinkle, J.L. CK. Brunner And Suddarth's Text Book Of Medical Surgical Nursing. 11th ed. 2010.

7. Reyes EB, Ha JW, Firdaus I, Ghazi AM, Phrommintikul A, Sim D, et al. Heart failure across
Asia: Same healthcare burden but differences in organization of care. Int J Cardiol [Internet].

2016;223:163-7. Available from: http://

dx.doi.org/10.1016/j.ijcard.2016.07.256

8. Majid A. Analisis faktor-faktor yang berhubungan dengan kejadian rawat inap ulang pasien gagal jantung kongestif di rumah sakitcYogyakarta. Universitas Indonesia; 2010.

9. Androne A, Hryniewicz K, Hudaihed A, Mancini D, Lamaca J, Katz S. Relation of unrecognized hypervolemia in chronic heart failure to clinical status, haemodynamics, and patient outcomes. Am J Cardiol. 2004;93(10):1254-9.

10. Lindholm M, Holst M, Stro A, Willenheimer R. Liberal versus restricted fluid prescription in stabilised patients with chronic heart failure: Result of a randomised cross-over study of the effects on health-related quality of life, physical capacity, thirst and morbidity. 2008;(December 2007):316-23.

11. Hahn RG, Jaarsma T, Waldre N. Thirst in heart failure : a systematic literature review. 2013;141-9.

12. Waldreus N, Sjeostrand F, Hahn R. Thirst in the elderly with and without heart failure. Arch Gerontol Geriatr. 2011;53:174-178.

13. Aliti GB, Rabelo ER, Clausell N, Rohde LE, Biolo A, Beck-da-Silva L. Aggressive Fluid and Sodium Restriction in Acute Decompensated Heart Failure. JAMA Intern Med. 2013;173(12):1058.

14. Allida SM, Inglis SC, Davidson PM, Lal S, Hayward CS, Newton PJ. Thirst in chronic heart failure: A review. J Clin Nurs. 2015;24(7-8):91626.

15. Sacrias, GG, Rathinasamy,E.L, Elavally, S and Arjunan P. Effect of nursing intervention on thirst and interdialytic weight gain of patients with chronic kidney disease subjected to hemodialysis. 2015;6(1):13-9.

16. Salata RA, Verbalis JG, Robinson AG. Cold water stimulation of oropharyngeal receptors in man inhibits release of vasopressin. J Clin Endocrinol Metab. 1987;65(3):561-7.

17. Weyland M. Your heart disease and fluid restriction. Peter Munk Card Centre. 2011;159(5).

18. Brunstrom JM, Macrae AW. Effects of Temperature and Volume on Measures of Mouth Dryness, Thirst and Stomach Fullness in Males and Females. 1997;31-42.

IMJM Volume 20 No.2, Apr 2021 
19. Obika LFO, Idu FK, George GO, Ajayi OI, Mowoe RS. Thirst perception and drinking in euhydrate and dehydrate human subjects. Niger J Physiol Sci. 2009;24(1):25-32.

20. Amerogen A. Ludah dan kelenjar ludah: Arti penting bagi kesehatan gigi. Yogyakarta: Gadjah Mada University Press; 1991. 6-22; 37-39 p.

21. Mohammad Affan Fajar Falah*, Putri Yuliastuti, Risma Hanifah PS dan J. Kualitas Buah Stroberi (Fragaria sp cv Holibert) Segar dan Penyimpanannya dalam Lingkungan Tropis dari Kebun Ketep Magelang Jawa Tengah. J Agroindustri. 2018;8(1):1-10.

22. Polit D, Beck C. Nursing Research, Principles and Methods. 7th ed. Philadelphia: Lippincott Williams and Wilkins; 2004.

23. Riegel B, Lee S, Hill J, Daus M, Baah FO, Wald JW, et al. Patterns of adherence to diuretics, dietary sodium and fluid intake recommendations in adults with heart failure. Hear Lung. 2019;48 (3):179-85.

24. Krueger S, Abraham WT, Jagielski D, Oldenburg O, Augostini R, Kolodziej A, et al. Phrenic nerve stimulation for the treatment of central sleep apnea. JACC Hear Fail. 2015;3(5):360-9.

25. Jankowska-Polanska B, Swiatoniowska-Lonc N, Slawuta A, Krówczynska D, Dudek K, Mazur G. Patient-Reported Compliance in older age patients with chronic heart failure. PLoS One. 2020;15(4):1 $-16$.

26. Ponikowski P, Voors AA, Anker SD, Bueno H, Cleland JGF, Coats AJS, et al. 2016 ESC Guidelines for the diagnosis and treatment of acute and chronic heart failure. Eur Heart J. 2016;37(27):2129-2200m.

27. Johansson P, Van Der Wal MHL, Strömberg A, Waldréus N, Jaarsma T. Fluid restriction in patients with heart failure: How should we think? Eur J Cardiovasc Nurs. 2016;15(5).

28. Szady A, Hill J. Diuretics in heart failure: A critical appraisal of efficacy and tolerability. Drugs. 2009;69:2451-2461.

29. Carpenter M. Human neuroanatomy. 7th ed. Baltimore: Williams \& Wilkins; 1976. 312, 352 p.

30. Guyton A. Textbook of medical physiology. 11th ed. Philadelphia: Elseiver; 2006. 